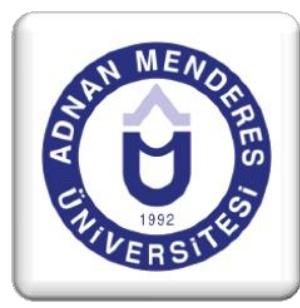

\title{
Yeni Soğuk Savaşa Doğru: Küresel Enerji Politikaları
}

\section{Towards a New Cold War: Global Energy Policies}

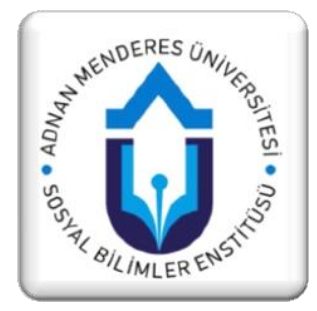

Sertan Çınar ${ }^{1}$, Yrd. Doç. Dr. İsmet Göçer ${ }^{2}$

\section{Özet}

Bu çalışmada, 1990 sonrası dönemde başta $A B D$ ve Rusya Federasyonu olmak üzere İran, Çin ve Avrupa Birliği ülkelerinin de dâhil olduğu geniş bir coğrafyada, Afrika, Ortadoğu ve Orta Asya'daki enerji kaynaklarına hâkim olmak için yaşanan yeni soğuk savaş ve söz konusu ülkelerin enerji politikaları incelenmiştir. Yaşanan küresel ve bölgesel üstünlük mücadelesi, bu coğrafyalarda ülkelerde iç karışıklıkların yaşanmasına, yönetimlerin el değiştirmesine, ülke sınırlarının değişmesine ve bölgenin yeniden şekillenmesine neden olmuştur. Bu çalışma, bölgede yaşanan olayların siyasi ve ekonomik sebeplerini incelemesi nedeniyle, ilgili literatüre bir katkı sağlaması beklenmektedir.

Anahtar Kelimeler: Yeni Soğuk Savaş, Enerji Politikaları, Rusya, ABD, AB.

\section{Abstract}

In this study, the new cold war between USA, Russian Federation, China, EU and Iran after 1990 that aimed at holding control of energy sources in the wide area of Africa, Middle East and Middle Asia and their energy policies were examined. The struggle for global and regional hegemony brought about insurgencies and administrational shifts in so-called countries, changes in the borders and reshaping of whole regions. This study is supposed to provide a contribution to the literature as it looks into the political and economic causes of what is happening there.

Key Words: New Cold War, Energy Policy, Russian, USA, EU.

\footnotetext{
${ }^{1}$ Muğla Sıtkı Koçman Üniversitesi, Sosyal Bilimler Enstitüsü, Kamu Yönetimi Bölümü, cinarsertan@hotmail.com, Muğla.

${ }^{2}$ Adnan Menderes Üniversitesi, Aydın İktisat Fakültesi, Ekonomi ve Finans Bölümü, igocer@adu.edu.tr, Aydın.
} 


\section{GİRIŞ}

Aralık 1991'de SSCB'nin dağılmasıyla birlikte, iki kutuplu dünya sona ermiş ve yerini Amerika Birleşik Devletleri (ABD) hegemonyası almıştır. Bu ortamda SSCB'den ayrılan bölgelerde önemli bir boşluk oluşmuştur (Erol ve Demir, 2012: 26, İyikan, 2009: 262). Moskova'nın merkez rolünün ortadan kalkmasıyla, sosyalizm etnik milliyetçiliğe evrilmiş ve birçok bölgede iç çatışmalar yaşanmıştır. Soğuk Savaşın sona ermesiyle birlikte, yoğun bir şekilde enerjiye ihtiyaç duyan ABD ile enerji kaynakları açısından zengin olan Rusya Federasyonu ve Azerbaycan, Kazakistan ve Türkmenistan gibi eski Sovyet Cumhuriyetleri karşı karşıya gelmiştir.

SSCB'nin dağılması sonucunda egemenlik alanının daralması nedeniyle Rusya Federasyonu'nun hem Baltık Denizi ve Karadeniz'e çıkışı kısıtlanmış, hem de Avrupa'yla olan doğrudan bağlantı yolları kapanmıştır. 1990'lı yılları istikrarsızlıklar ve ekonomik zorluklarla geçiren Rusya Federasyonu, 2000 yılında Vladimir Putin'in Devlet Başkanı seçilmesiyle birlikte, yeniden büyük güç olma vizyonunu yakalamıştır.

Rusya ve ABD arasında Soğuk Savaş sonrası dönemde ortaya çıkan, Avrasya enerji kaynaklarının kontrolü, NATO'nun genişlemesi ve Doğu Avrupa Füze Kalkanı projesi gibi konular, iki ülke arasındaki gerilimi daha da artırmıştır. 2000'li yıllarda önce Kosova'da, arkasından Gürcistan'da meydana gelen çatışmalar, iki ülke arasındaki sorunları daha da derinleştirmiştir.

11 Eylül 2001 saldırıları sonrasında NATO'nun SSCB'nin etki alanında bulunan bölgelerdeki genişleme çabaları, Batı ile Rusya Federasyonu arasındaki ilişkileri olumsuz yönde etkilemiştir. ABD, Soğuk Savaş döneminde SSCB'ye karşı uyguladığı çevreleme politikasını, çemberi daha da daraltarak Rusya'nın yanı sıra Çin'e karşı da uygulamaya koymuştur. Bu çerçevede Gürcistan ve Ukrayna gibi çevre ülkelerde renkli devrimlerle demokratikleşme çabaları desteklenip, neoliberal reformlar teşvik edilmiştir (Nogaieva, 2010: 62). Enerji arz güvenliğini sağlamak isteyen ABD, 11 Eylül saldırılarını bahane ederek, teröre karşı mücadele kapsamında Irak ve Afganistan'a operasyonlar düzenlemiş, Ortadoğu ve Orta Asya'daki zengin petrol ve doğal gaz kaynaklarını kontrolü altına alabilmek amacıyla bölge ülkelerinde askeri üsler kurmuştur.

$\mathrm{Bu}$ süreçte, iki kutuplu dünyanın yerini, ilk başta $\mathrm{ABD}$ merkezli tek kutuplu dünya almıştır. Ancak sonrasında enerji politikalarını bir silah olarak kullanan Rusya, sosyalist rejimini neoliberal uygulamalarla destekleyen ve ekonomik olarak hızla büyüyen Çin, bünyesine kattığı yeni ülkelerle üye sayısını 28'e çıkaran ve önemli bir güç haline gelen Avrupa Birliği'nin (AB) yanısıra Brezilya ve İran gibi bölgesel güçlerin de ortaya çıkmasıyla birlikte, sistem çok kutuplu hale gelmeye başlamışır (Yılmaz, 2008: 32). ABD’nin bölgedeki etkisinin azalması, Ortadoğu ve Hazar Denizi gibi petrol bölgelerinde silahlı çatı̧̧ma riskini artırmıştır. Ayrıca ABD’nin siyasal ve ekonomik etkisini sürdürmek ve genişletmek için, bir taraftan önceden Rusya'ya bağlı olan bölgelerde demokrasiyi önceleyip (Nogaieva, 2010: 64), diğer taraftan Ortadoğu'da otokratik rejimleri desteklemesi, bir çelişki olarak ortada durmaktadır.

Bu çalışmada 1990'dan sonra, iki kutuplu dünyadan tek kutuplu dünyaya geçişten sonra oluşan soğuk savaş sonrası ortamı ve söz konusu ülkelerin enerji politikaları değerlendirilmektedir. Putin'le başlayıp, başta enerji konusu olmak üzere, günümüze kadar yaşanan küresel ve bölgesel üstünlük mücadelesi bu çalışmanın başlıca konusu olacaktır. Bu çerçevede çalışmanın ikinci bölümünde; Soğuk Savaş'ın sonunu getiren süreçle ilgili bir değerlendirme yapılacak, üçüncü bölümde; Soğuk Savaş sonrasında ortaya çıkan uluslararası sistem analiz edilecek, dördüncü bölümde Amerikan, beşinci bölümde Rus dış politikaları mercek altına alınacaktır. Altıncı bölümde; enerji politikaları bağlamında Rusya-ABD mücadelesi incelenecek, sonuç ve önerilerle çalışma tamamlanacaktır. İncelenen konunun güncelliği ve önemi itibariyle çalışmanın literatüre bir katkı sağlayacağı öngörülmektedir.

\section{SOĞUK SAVAŞ}

Uluslararası siyasetin büyük aktörleri; 20. yüzyılın ilk yarısında Avrupa devletleri, ikinci yarısında ise ABD ve Sovyet Sosyalist Cumhuriyetleri Birliği (SSCB) olmuştur. İkinci Dünya 
Savaşından sonra İngiltere, yüzyıllardır hâkim olduğu Orta Doğu Bölgesinden çekilip yerini ABD’ye bırakmak zorunda kalırken (Nurpeiis, 2013: 520), Marksist ideolojisini dünyaya yaymaya çalışan Sovyet Rusya ile ABD arasında (Armaoğlu, 1983: 511) 1989'a kadar devam edecek olan bir mücadele yaşanmıştır.

ABD İkinci Dünya savaşıyla izlediği "yalnızcılık politikasını" terk ederek, dünyanın çok farklı bölgelerinde askeri üsler açmıştır. Pearl Harbour Baskını ${ }^{4}$ dışında ABD topraklarında sıcak bir çatışmanın yaşanmamış olması, bu ülkenin ekonomisinin, diğerleri kadar zarar görmesini engellemiştir (Özkan, 2011: 62).

SSCB'nin nükleer kapasitesini artırarak ABD'yle rekabet edebilir hale gelmesi sonucunda bir "dehşet dengesi" oluşmuştur. Her iki blokun da çakılacak bir kıvılcımın kendi ülkesini de mahvedeceğinin bilincinde olması, iki güç arasında doğrudan sıcak bir çatışmanın yaşanmasını engellemiştir. Bunun yerine Kore, Vietnam ve Afganistan gibi çevre ülkelerde, dünyayı nükleer bir felaketin eşiğine getirmeyecek düşük yoğunluklu çatışmalar ve krizler yaşanmıştır.

İkinci Dünya savaşı sonrası dönemde SSCB, devlet müdahaleciliğine dayalı özel mülkiyetin olmadığı planlı ve sosyalist bir ekonomiyi benimserken Batı, Keynesçi ${ }^{6}$ refah devleti politikalarını uygulamıştır. Bunun sonucunda Batı ülkelerinde 1973 petrol krizine kadar sürecek olan uzun bir refah dönemi yaşanmıştır'. 1980'lerin başında ABD'de Ronald Reagan, İngiltere'de ise Margaret Thatcher'ın iktidara gelmesiyle birlikte; ülkede kullanılabilir nihai mal ve hizmet miktarının arttırılmasının hedeflendiği, özelleştirmelerin hız kazandığı, devletin üretim faaliyetlerine müdahil olmadığı ve denetleyici rolüne büründüğü, enflasyonun kontrol altında tutulmasının birincil amaç olduğu arz yönlü iktisadı temel alan neoliberal politikalar benimsenmeye başlamıştır. Sonuç olarak, Batıdaki liberal ekonomi 1970'li yıllardaki ekonomik krizlerle birlikte, çalışanların aleyhine bir dönüşüm yaşayıp, ayakta kalmayı başarırken, doğudaki sosyalist ekonomi varlığını sürdürememiştir (Gürkan ve Karahanoğulları, 2013: 17).

Soğuk savaş boyunca birçok devlet ya ABD ya da SSCB'nin yanında yer almıştır. Güney ülkelerinde sosyalist-milliyetçi isyanlarla, sanayileşmiş kapitalist sömürgeci devletlere karşı anti kolonyal bir mücadele başlamış ve bu mücadele Doğu blokunun desteğini almıştır. Bu sürecin sonucunda art arda bağımsızlıklarını kazanan bu devletler "Bağlantısızlar Hareketini" kurmuşlardır (Nurpeiis, 2013: 522). Sonuç olarak, İkinci Dünya savaşına kadar Avrupa merkezli cereyan eden Uluslararası Politikanın alanı, kanatlara yayılmış ve yeni küresel aktörler belirleyici rol üstlenmeye başlamışlardır.

\footnotetext{
3 Yalnızcılık Politikası veya İzolasyonizm; daha çok politik bir terim olarak, kendini diğer ülkelerin sorunlarından ve dünya politikasından uzak tutan devletlerin statejik politikalarını tanımlamak için kullanılmaktadır (Sümer, 2008: 121).

4 Japon İmparatorluk Deniz Kuvvetleri'nin 7 Aralık 1941'de Hawaii yakınlarında yer alan Oahu adasında bulunan ABD Pasifik Filosu ve Pearl Harbor askerî üslerine karşı düzenlediği sürpriz saldırıdır (Doğan, 2012 : 91).

5 Dehşet Dengesi, Terör Dengesi ya da Karşılıklı Mahvolma politikası da denilen bu kavram; nükleer güce sahip devletlerarasında çıkabilecek olası bir nükleer savaşta, ortaya çıkacak topluca yok olma korkusu nedeniyle ülkelerin sergilediği temkinli davranışı ifade etmektedir (Kibaroğlu, 2002: 2).

6 1936'da John Mynard Keynes'in “İstihdam, Faiz ve Paranın Genel Teorisi” adlı kitabının yayınlanmasıyla başlayan, ekonomik durgunluk dönemlerinde devletin genişletici para ve maliye politikaları ile ekonomiye müdahale etmesi gerektiğini, diğer zamanlarda ekonominin kendi seyrine bırakılması gerektiğini ifade eden ekonomik teoridir (Y1ldırım vd. 2010: 1267)

${ }^{7} \mathrm{Bu}$ döneme "long boom yılları" adı verilmiştir (Aykaç vd. 2009: 42).
} 


\section{SOĞUK SAVAŞ SONRASI ULUSLARARASI SISTEM}

Gramsci $^{8}$ ye göre bir sınıfın hegemon olabilmesi için kendi kültürünü, fikirlerini ve dünya görüşünü toplumun diğer sınıflarına kabul ettirebilmesi gerekmektedir. Bu katmanlar hegemonyayı doğal ve vazgeçilmez olarak algıladıklarında, egemen sınıfın iktidarını devam ettirebilmesi kolaylaşacaktır. $\operatorname{Cox}^{9}$ 'a göre ise hegemonya, güçlü olan devletin yöneticilerinin fikir ve davranışlarından beslenir. Böylece belirli ülkeler, dünya genelinde etkili olabilmek için, ekonomik, askeri ve siyasal güç odaklarını harekete geçirerek, diğer ülkelerle güç yarışına girmiş̧ir (Çiftçi, 2009: 211). Soğuk savaş yılları olarak adlandırılan 1947-1991 yılları arasında ABD ve Rusya'nın dünya üzerinde hâkim olma ideolojisini gerçekleştirmede başvurdukları yollar, Gramsci-Cox çizgisinde bir hareket tarzını çağrıştırmaktadır.

Klasik ekonomi teorisinin kurucusu Adam Smith'in 1776 da yayınlanan Ulusların Zenginliği kitabında üzerinde önemle durulan ve zaman içinde bütün dünya ülkelerinde kabul gören düşünceye göre ulusların zenginliğinin yolu; iş bölümü, uzmanlaşma ve serbest dış ticaretten geçmektedir (Smith, 1776: 77). Adam Smith'in bu fikirleri Batı ülkeleri tarafından, geri kalmış Üçüncü Dünya ülkelerine özellikle yayılarak, o ülkeler üzerindeki etkinliklerini arttırma ve ülke kaynaklarına rahat müdahale edebilme imkânı elde edilmiştir.

SSCB yıkıldıktan sonra bu alanda bir boşluk oluşmuş, siyasi yörüngesini kaybeden eski SSCB üyesi ülkelerde milliyetçilik artmış ve Soğuk Savaş koşullarında nispi bir istikrar olan bu ülkelerde, demir perdenin yıkılmasından sonra iç karışıklıklar çıkmıştır (İyikan, 2009: 257). Özellikle eski Sovyet topraklarındaki zengin doğal kaynaklar, etnik çatışmalar ve radikal örgütler, kaotik bir ortam oluşturmuştur. Hatta nükleer silahların bile bu örgütlerin eline geçme tehlikesi baş göstermiş̧tir (Önal, 2010: 52). ABD, özellikle 11 Eylül 2001 saldırılarından sonra, bu bölgede yaşanan gelişmelere etkin biçimde müdahale etmeye başlamış, bu konuda askeri, ekonomik ve siyasi bütün imkânlarını seferber etmiştir. Böylece ABD, askeri üsler kurarak Avrupa'dan Çin'e kadar geniş bir coğrafyada nüfuz oluşturma imkânını yakalamıştır. Henüz askeri ve ekonomik açıdan güçsüz olan Rusya Federasyonu, bu bölgedeki örgütlerle giriştiği mücadelenin kendine sağlayacağı faydadan dolayı, başlangıçta ABD'nin bu operasyonlarını desteklemiştir. Ancak ilerleyen süreçte ABD'nin bu operasyonları, başta Shangai İşbirliği Örgütü ${ }^{10}$ devletleri olmak üzere, bölge ülkelerinin büyük tepkisini çekmiş ve bölgede ABD’ye yeni ittifak arayışlarının da yolunu açmıştır (Nurpeiis, 2013: 523).

Rusya-AB ilişkileri Rusya'nın entegre olmak istediği dünya ekonomik düzeni ve ticari ilişkiler açısından büyük öneme sahiptir. $\mathrm{AB}$, bu ilişkide Rusya Federasyonunun kendisine bağlanmasını öngörürken, Rusya olaya daha güvenlik odaklı yaklaşmaktadır. Ayrıca Rusya, AB'nin komşuluk politikaları uyarınca sınırlarını Rusya'ya kadar genişletmesine de karşı çıkmaktadır (Özer, 2008: 172).

Avrupa ülkelerinin bütünleşme yönünde ileri adımlar atması, Çin'in artan ekonomik gücü ve Rusya'nın ABD hegemonyasına gösterdiği direnç, ABD merkezli tek kutuplu dünya algısını önemli ölçüde sekteye uğratmıştır (Çiftçi, 2009: 209). Özellikle Çin'in hızlı yükselişi, ABD hegemonyası için önemli bir tehdit oluşturmaktadır. Tayvan, Tibet ve Uygur Özerk Bölgesi gibi konularda zaman zaman gerilim yaşansa da Çin, yaptığı revizyonlarla, kapitalist sisteme hızlı biçimde entegre olmakta ve dünya düzeninde etkili bir aktör haline gelmeye devam etmektedir (Gökten, 2011: 115).

\section{SOĞUK SAVAŞ SONRASI ABD DIŞ POLITITIKASI}

\footnotetext{
${ }^{8}$ İtalyan düşünür, siyasetçi ve sosyalist kuramcı olan Antonio Gramsci (1891-1937), Mussolini rejimi tarafından hapse atılmış, burada yazdığı Hapishane Defterleri adlı üç ciltlik eserinde, hegemonya, sivil toplum, altyap1üstyapı ilişkileri ve toplumda aydınların işlevi hakkındaki görüşlerini paylaşmıştır (Aka, 2009: 333).

91926 ABD doğumlu olan Rocert Cox, Gramsci’nin fikirlerinden yararlanarak, hegemonya kavramına uluslararası ilişkiler bağlamında yeni bir içerik kazandıran politik iktisatçıdır (Schouten, 2009: 2).

${ }^{10}$ Çin, Rusya, Kazakistan, Kırgızistan ve Tacikistan tarafından 1996'da Çin'in Şanghay kentinde kurulan bu ittifak, 2001'de Özbekistan'ın da katılımıyla üye sayısını altıya çıkarmıştır.
} 
ABD dış politikasına, bu ülke içindeki gelişmelerle birlikte bakmakta yarar vardır. Çünkü bu ülkedeki hâkim sınıflar, ABD dış politikanın yürütülmesinde, kendi çıkarlarının gerçekleştirilmesi için, ABD ulusal çıkarlarıyla kendi çıkarlarını aynı çizgiye çekmeye çalışmaktadırlar.

İkinci Dünya Savaşına kadar savaşın önlenmesi gereken bir olgu olduğunu öngören ABD Dış Politikası, sonraki süreçte savaşı meşrulaştırıp amaçlarına ulaşmak için bir vasıta olarak kullanmaya başlamıştır. Asker, siyaset ve silah endüstrisi arasındaki girift ilişkiler ağı, ABD dış politikasında soğuk savaş mantı̆̆ının 1990'larda bile devam etmesine neden olmuştur. Bunun etkileri, ABD'nin dünyanın farklı bölgelerinde yürüttügü askeri operasyonlarda da görülmüştür. 1960'larda ABD'de artan özgürlük ve hak taleplerine karşıllk, milliyetçi/muhafazakâr bir tepki gelişmiş ve bu gruplar 1980'lerden itibaren iktidar mücadelesine girişmiştir.

ABD'de Vietnam Savaşı'ndan alınan derslerle hazırlanan askerî müdahale doktrininin yerini, Birinci Körfez savaşıyla birlikte orduyu dünyanın dört bir yanında savaşlara sokan politikalar almıştır. Bu savaşların amaçları önceden belirlenmiş olmasına karşın, sonuçları için aynı şeyi söylemek güçtür. ABD ordusunun Bosna, Kosova ve Afganistan'da kazandığı zaferler, Amerikalı politikacıları yanıltmış ve bunun sonucunda ABD ordusu, 2003'teki Irak'a girerek Orta Doğu'da batağa saplanmıştır (Özkan, 2011: 57).

SSCB'nin yıkılmasıyla kendi hegemonyasını meşrulaştıran "düşmanından” mahrum kalan ABD, gerekli gördüğ̈̈ yerlere müdahalelerde bulunabilmek için belli bölgelerde denetimli bir istikrarsızlık ortamı oluşturma yolunu seçmiştir (Polat, 2006: 72). Böylece hegemon olarak ABD'nin askeri gücüne ihtiyaç duyulması planlanmıştır. Ancak hem Birleşmiş Milletler (BM) Güvenlik Konseyi'nde hem de Uluslararas1 Para Fonu'nda (International Money Fund: IMF) en etkin devlet olarak ABD'nin bu noktada uluslararası kuruluşları görmezden gelmesi, izlediği politikaların meşruiyetinin sorgulanmasına yol açmıştır (Çiftçi, 2009: 212).

Berlin Duvarının 1989'da yıkılmasından, 1990'daki Birinci Körfez Savaşı'na kadar olan süreçte ABD içinde, ülkenin bundan sonraki dış politikasına iliş̧kin bir dizi tartışma yaşanmıştır. Bazı siyasetçi ve düşünürler izolasyonist politikalara dönmek gerektiğini savunurken (Yılmaz, 2008: 33), bazıları da ABD'nin ittifaklar yoluyla hegemon rolünü devam ettirmesi gerektiğini öne sürmüşlerdir. Baba Bush ${ }^{11}$ yönetimi ise bunu Pax-Americana ${ }^{12}$ 'nın gerçekleştirilmesi için bir firsat olarak görmüştür (Önal, 2010: 55). 1992'de Paul Wolfowitz'in hazırladığı raporda, “ABD’nin birinci önceliğinin kendine meydan okuyacak bir süper gücün ortaya çıkmasını engellemek olduğu" ifade edilmiştir (Katzman, 2005: 2). Bu görüşe göre; eski Sovyet coğrafyasını da içine alan Doğu Asya ve Orta Doğu'nun kontrol altında tutulması çok önemliydi. Sonraki süreçte, ABD'nin değişik coğrafyalarda diplomasiden çok askeri güce başvurması, bu politikanın izdüşümü olarak değerlendirilebilir (Özkan, 2011: 61).

ABD'nin dış politikadaki diğer bir önceliği de yurtdışında yatırım yapan Amerikan ve Batılı petrol şirketlerinin güvenliğini sağlamaktır. Ülke yöneticileri tarafindan bu şirketlerin çıkarları, Amerikan ulusal çıkarlarıyla eşdeğer kabul edilmektedir (Önal, 2010: 66). Ortadoğu gibi riskli bölgelere yapılan askeri müdahalelerin önemli bir gerekçesi de buralarda yatırımı bulunan ABD’li enerji firmalarının güvenliğinin sağlanmasıdır. ABD bu yolla aynı zamanda ülkesinin enerji arz güvenliğini de garanti altına almayı amaçlamaktadır (İyikan, 2009: 259).

\subsection{Demokratikleşme ve Amerikan Hegemonyası}

ABD'nin Orta Asya politikası güvenlik, enerji ve demokrasi temelinde şekillenmiştir (Yılmaz, 2008: 35). Demokrasiyi araç olarak kullanan ABD, bir taraftan müdahale etmek istediği devletten üstün olduğu izlenimini uyandırırken, diğer yandan da "ötekileri" tarafına çekmeye çalışmaktadır

\footnotetext{
${ }^{11}$ George Herbert Walker Bush, Amerika Birleşik Devletleri'nin 41. Başkanı olup, 1988-1992 döneminde ABD'yi yönetmiş, bu süreçte Kuveyt'e saldıran Irak'a karşı askeri güç kullanma kararı vermiştir. Amerika Birleşik Devletleri'nin 43. başkanı olan George W. Bush'un babasıdır.

${ }^{12}$ Amerika Birleşik Devletleri’ne askeri ve diplomatik olarak modern zamanların Roma İmparatorluğu (dünyanın jandarmalığı) rolünü yükleyen düşünce.
} 
(Nogaieva, 2010: 66). Bu bağlamda demokrasi, ABD’nin kendi çıkarlarını gerçekleştirmek amacıyla kullanılan bir araçtan öteye gitmemektedir. Doğu Avrupa'da, SSCB'nin dağılmasından çok önce başlayan demokratikleşme çabalarını kendi lehine çevirmeye çalışan ve bölge ülkelerini insan hakları ihlalleri konusunda baskı altına alan ABD yönetiminin asıl amac1, bölgedeki Sovyet uydusu konumundaki devletleri tarafına çekmek olmuştur. Liberal demokrasinin, insanlık tarihinin gelişiminin kaçınılmaz bir sonucu olduğunu ilan eden "Reagan Doktrini" demokratikleşme süreçlerinin komünizmle mücadele için kullanılmaya başlandığı zaman diliminin başlangıcı olarak kabul edilebilir. $\mathrm{Bu}$ çerçevede Nikaragua, Angola ve Afganistan gibi ülkelerde çıkan anti-komünist ayaklanmalar desteklenmiştir (Nogaieva, 2010: 67).

Soğuk savaşın bitmesinden sonra on yıllık sürede ABD'nin ekonomik, siyasi ve sosyal modelleri dünyada etkili olmaya başlamıştır. Oğul Bush ${ }^{13}$ yönetimi, ABD'yi doğrudan ilgilendirmeyen sorunlara ilgisiz kalarak, Bill Clinton döneminde kurgulanan "Pax Americana" nın bittiğini ilan etmiştir. 11 Eylül 2001 saldırıları sonucunda ise ABD'nin dış politikada rızaya dayalı hegemonyadan, zora dayalı hegemonyaya geçiş yaptığı söylenebilir (Çiftçi, 2009: 214). 11 Eylül saldırılarıyla birlikte aradığı fırsat1 ele geçiren ABD yönetimi, Irak ve Afganistan'a gerçekleştirdiği askeri operasyonlarla dünyanın hala Amerikan askeri gücüne ihtiyacı olduğunu göstermeye çalışmıştır (Özkan, 2011: 69). Küresel terörün kaynă̆1 olduğunu iddia ettiği Afganistan ve Irak'a yapılan ABD müdahaleleri, terör ve ayrılıkçı gruplarla mücadele eden Rusya ve Çin'in elini güçlendirmiştir. Demokratik bir geleneğe sahip olmayan Orta Asya ülkelerindeki Amerika destekli demokratik devrim girişimleri, Rusya ve Çin tarafından bölgeye istikrarsızlık getirecek girişimler olarak tanımlanmıştır. Irak'ın işgaliyle, ABD dikkatini daha çok Orta Doğu'ya çevirmiştir (Blank, 2007: 47).

ABD demokratikleştirme dalgasının, otoriter Çin ve Rusya Federasyonu'nun yükselişe geçmesiyle sekteye uğrayabileceğinden endişe etmektedir. $\mathrm{Bu}$ yüzden $\mathrm{ABD}$, eski Sovyet uydusu konumundaki bu ülkelerde STK'lar, Gönüllüler ve GUAM Örgütü ${ }^{14}$ yardımıyla demokratik renkli devrimler yapma yoluna gitmiştir (Nogaieva, 2010: 71). Sovyetlerden bağımsızlığını kazanmış olan yoksul ülkeler, suç örgütleri için çok büyük olanaklar sunmaktadır. AB'nin genişlemesinin bir sonucu olarak sınırlarının geçirgenliğinin artması, Avrupa ülkeleri için bu örgütlerin bir tehdit oluşturmasına neden olmaktadır. $\mathrm{Bu}$ bağlamda $\mathrm{AB}$, kendi güvenliği için Rusya federasyonunun dönüşerek demokratik ve liberal ilkeleri benimsemesini beklemektedir. Ancak görünüşte Rusya Federasyonunun böyle bir niyeti yoktur (Özer, 2008: 175).

Hem küresel finans krizi, hem de Bush döneminde izlenen yalnızlaştırıcı politikaların sonuçlarını azaltmaya çalışan Barack Obama'nın Kasım 2008'de iktidara gelmesi ile yeniden rızaya dayalı hegemonyaya dönüşün başladığı değerlendirilmektedir (Çiftçi, 2009: 215).

\subsection{Yeni Düşman: Radikal İslam}

ABD, özgürlüklerin savunucusu olarak ihtiyaç duyduğu düşmanı, radikal İslam'da bulmuştur. İran'ın kuzeyinde yer alan altı Müslüman ülkenin ${ }^{15}$ bağımsızlıklarına kavuşması, ABD'yi bu ülkelere İran'ın rejim ihracı riski konusunda ciddi biçimde tedirgin etmiştir. Buna karşılık ABD, bu devletlere Türkiye'yi örnek göstererek ve Orta Asya'da askeri üsler kurarak Çin, Rusya ve İran'ın bölgedeki etkisini kontrol altında tutmayı amaçlamıştır (İyikan, 2009: 264).

11 Eylül 2001 saldırıları ve o dönemde medyada Afganistan'la ilgili olarak yayınlanan insanlık dış1 görüntüler, Amerika'nın 7 Ekim 2001'de bu ülkeye yönelik müdahalesinin destek bulmasını kolaylaştırmıştır. Ancak sonrasında Irak'a yapılan müdahalenin gerekçelerini anlatmakta zorlanan Bush yönetimi yanında İngiltere'den başka destek bulamamıştır (Çiftçi, 2009: 211).

\footnotetext{
${ }^{13}$ George Walker Bush, Amerika Birleşik Devletleri'nin 43. Başkanı olarak 20 Ocak 2001 - 20 Ocak 2009 tarihleri arasında bu görevi yürütmüştür. Döneminde ABD’nin Afganistan ve Irak’a yaptığı askeri müdahalelerle anılmaktadir.

${ }^{14}$ Gürcistan, Ukrayna, Azerbaycan ve Moldova'nın bir araya gelmesiyle 10 Ekim 1997'de kurulan birliğe 19992005 yılları arasında Özbekistan da üye olmuştur.

${ }^{15}$ Azerbaycan, Özbekistan, Türkmenistan, Tacikistan, Kırgızistan ve Kazakistan.
} 
SSCB'ye karşı kullanılan dini grupların, soğuk savaşın sona ermesiyle güçlenmesi sonucunda $\mathrm{ABD}$, askeri güce başvurmuştur. Bundan sonraki süreçte bölgeye yapılan yardımlarda, demokrasi ve serbest piyasanın geliştirilmesi şartı aranmıştır. Ancak Afganistan ve Irak operasyonlarında bu söylemin kullanılması ciddi bir çelişki yaratmıştır. Eski Sovyet uydularında gerçekleştirilen renkli devrimler ise demokrasinin bir hedef olmaktan ziyade ABD ve Batı yanlıs olmakla özdeşleştirilmesine neden olmuştur (Nogaieva, 2010: 72).

ABD konjonktüre göre hareket etmiş, 1990'larda Taliban'1 desteklerken, 11 Eylül sonrasında bu rejimi düşman ilan etmiştir. Bush 2002'de yaptığı bir konuşmada çevreleme politikasının hedefleri uğruna intihardan çekinmeyen teröristlere kucak açacak diktatörlere karşı artık yetersiz olduğunu ifade etmiştir. Bu süreçte gündeme gelen "önleyici müdahaleyi ${ }^{16 ”, ~ I r a k ' a ~ y a p ı l a c a k ~ m u ̈ d a h a l e y i ~ m e s ̧ r u ~}$ göstermek için ortaya atılmış bir strateji olarak görenlerin yanında, onun ABD'nin meşruiyetini ve güvenilirliğini sarsacağını ve diğer devletlerin de kendi önleyici müdahale stratejilerini gündeme alacağını savunanlar da olmuştur (Tunç, 2009: 4).

\section{SOĞUK SAVAŞ SONRASI RUS DIŞ POLITIKASI}

Tarihi boyunca Batıcılık ve Avrasyacılık akımlarından etkilenen Rusya, kültürel olarak ne batılı ne de doğulu bir toplum olabilmiştir. I. Petro ile başlayan Batıcılık; Batıyla mücadele edebilmek için onların teknik üstünlüğünden yararlanma olarak tanımlanabilir. Avrasyacılık ise Bolşevik devrimine muhalefet eden bir grup tarafindan ortaya atılmış olup Rusya'nın, Avrupa'dan farklı bir coğrafi ve kültürel yapıya sahip olduğunu, devlet sisteminde Moğol imparatorluklarından etkilendiğini savunmaktadır (Sönmez, 2010a: 42).

SSCB'nin ABD ile girdiği silahlanma yarışı sonrası ekonomisi ağır yara almıştır. SSCB'de Mihail Gorbaçov'un 1985'te iktidara gelmesiyle izlemeye başladığı Glasnost (açıklık) ve Perestroyka (yeniden yapılandırma) politikaları, içeride bir çözülmeye, dışarıda ise uluslararası sistemin yeniden şekillenmesine yol açmıştır (Çiftçi, 2009: 209). Sonuçta kutuplardan biri çökmüş, ABD rakipsiz kalmıştır.

SSCB'nin dağılmasıyla 1991'de oluşturulan Rusya Federasyonunun dış politikası, Gorbaçov'un yeni düşünüşünün devamıdır. Gorbaçov, Stalinist-Brejnevist askeri-siyasal mirası reddederek Çin'le barışmış ve Afganistan'dan orduyu çekmiştir. Böylece Batıyla işbirliği yapma yolunu seçmiştir. Gorbaçov'dan sonra iktidara gelen Boris Yeltsin de bu işbirliğini devam ettirmeyi tercih etmiştir. Yeltsin bu sürecin, Rusya'da serbest piyasa ekonomisine dayanan demokratik bir rejimin kurulmasına katkısı olacağına inanmaktaydı. Ancak hızla yürürlüğe giren ekonomik reformlarla birlikte ekonomik dengelerin kötüye gitmesi, Batıcılığa karşı bir tepki oluşmasına neden olmuştur (Sönmez, 2010a: 70). Yeltsin'in izlediği adem-i merkeziyetçi idari yapılanma sonucunda, Çeçenistan gibi bazı bölgelerde sorunlar yaşanmış ve bu bölgeler hızla merkezden uzaklaşmıştır. Rusya'nın terk etmeye başladığı bölgelerde 1989'da başlayan geri çekilme durdurulamamıştır. Doğu Avrupa, Güney Kafkasya ve Orta Asya'da eski müttefikler ya Batı'ya yaklaşmış ya da yalnız kalmıştır (Sönmez, 2010b: 80).

1994'ten sonra daha bağımsız bir dış politika izlemek isteyen Rusya, eski Sovyet topraklarında etkili olmak istemiştir. (Cankara ve Cankara, 2007: 200). Bu kapsamda Rusya Federasyonu, ABD tehdidine karşı arka bahçesi olarak gördüğü Kafkasya ve Orta Asya'da "Yakın Çevre Politikası"nı geliştirmiş ve eski SSCB üyeleriyle Bağımsız Devletler Topluluğu'nu kurmuştur. Rusya Federasyonu bir taraftan da ABD'nin sorun yaşadığg İran'1 desteklemeyi sürdürmüştür (İyikan, 2009: 261). Rusya Federasyonu, nükleer silahlanma konusunda da İran'ın yanında yer alarak ABD'nin bölgedeki etkinliğini azaltmaya çalışmıştır. ABD hegemonyasını çeşitli uluslararası platformlarda eleştiren Rusya Federasyonu ve Çin'e göre, Taşkent Kolektif Güvenlik Teşkilatı'na üye Orta Asya devletleri tarafından oluşturulan güvenlik birimiyle birlikte, bölgede ABD'nin askeri gücüne ihtiyaç kalmamıştır (Nurpeiis, 2013: 522).

\footnotetext{
${ }^{16}$ Bir tehdit olasılığg olduğunda, o tehdidin gerçekleşmesini beklemeden müdahale etmek. Bu ABD’ye göre meşrudur. Çünkü tehdit bir kere gerçekleşti mi, iş işten geçmiş olabilir. Irak’a müdahale konusunda ileri sürülen sav budur (Türkmen, 2002: 1).
} 
ABD'nin Avrasya bölgesinde gerçekleştirdiği siyasi ve askeri operasyonların Rusya Federasyonu ve Çin'i rahatsız etmesi sonrasında bu devletler 1996'da Shangai İşbirliği Örgütü'nü kurmuştur. İran bu örgüte 2005'te gözlemci statüsüyle dâhil olmuştur (Çoğal, 2014: 4). Shangai İşbirliği Örgütü, zaman içinde genişleyerek ABD'ye karşı yeni bir kutup haline gelmiştir.

İktidarı 2000'de Yeltsin'den devralan Putin, otoriteyi kısa sürede tesis etmiş ve merkezi yönetimi kuvvetlendirmiştir. Bölge valiliklerini feshederek, bölgelerin ülke politikası üzerindeki etkisini sonlandırmıştır (Sönmez, 2010a: 71). Bu sayede bölgede yeni istikrarsızlıklardan çekinen Avrupa devletleri, bu otoriter yapıya karşı sessiz kalmıştır (Özer, 2008: 178). Putin'in ülkede 1990'l1 yıllarda oluşan Yahudi oligarklara ${ }^{17}$ karşı giriştiği mücadeleden galip çıkması ve vergi vermekten kaçınan iş adamlarını kontrol altına almasıyla, ülkede merkez-çevre ve devlet kurumları arasındaki çatışmalar son bulmuş, ekonomik ve siyasi istikrar sağlanmış ve ülkeye yabancı sermaye girişinde ciddi artışlar kaydedilmiştir. Putin'in iktidara gelmesiyle birlikte Yeltsin döneminde ortaya çıkan disiplinsizlik ortadan kalkmış ve ekonomide olumlu sonuçlar alınmaya başlamıştır (Yalçıner, 2007: 241). Putin'in yeni Ulusal Güvenlik ve Dış Politika Doktrini ile ekonomik çıkarların diş politikadaki yeni öncelik olacağı belirtilmiştir. Bir başka deyişle, 1999'a kadar Rus dış politikasında temelini oluşturan askeri çevreler etkisini yitirmiştir (Mikail, 2007: 220-221).

Putin, yaptığı değişik düzenlemelerle, özerk cumhuriyetler üzerindeki kontrolünü artırmıştır. Sivil toplum kuruluşlarını kontrol altına almış ve özerk cumhuriyetlere, Kiril alfabesi kullanma zorunluluğunu getirmiştir. Bir yandan da serbest piyasaya geçiş sırasında uygulanan şok terapinin etkilerini azaltmaya çalışmıştır. Bunun için askeri-sanayi kompleksini harekete geçirmiş ve doğal kaynakları seferber etmiştir (Sönmez, 2010b: 81). Rusya, AB ve Türkiye gibi yakın komşularıyla uzun süreli doğal gaz anlaşmaları yaparak, enerji ticaretini sağlama almıştır. Son yıllarda dünyada doğal gaza olan talep artışı, bu konuda Rusya’yı dünyada daha fazla söz sahibi durumuna getirmiştir.

Aynı dönemde petrol fiyatlarında meydana gelen ciddi artışlar, Rus ekonomisinin gelişmesinde belirleyici rol oynamıştır. Rusya 2012'deki 2 trilyon dolarlık gayri safi yurtiçi hasılasının \% 15 'ini yani 310 milyar dolarlık kısmını petrolden elde etmiştir ${ }^{18}$. Rusya Federasyonu, zaman içinde enerji kartını etkili biçimde kullanarak, Avrasya'da çok geniş bir alanda nüfuzunu devam ettirmiştir.

NATO'nun 1999'da gerçekleştirdiği Kosova harekâtı, 2008 Gürcistan Savaşı ve 2014 Ukrayna ve Kırım olayları, Rusya-NATO ilişkilerini iyice germiştir. Böylece, bu döneme kadar süren iyimser hava dağılmıştır. ABD'nin NATO içindeki başat konumundan rahatsız olan Rusya, Putin döneminde ABD'yi dengelemek amacıyla AB'ye yaklaşmıştır. Bunun teorik temellerini, Batıyla eşit ve karşılıklı çıkar anlayışına dayanan bir ilişki kurulmasını savunan Primakov Doktrininde ${ }^{19}$ görmek mümkündür.

11 Eylül saldırıları da Putin'in elini güçlendirmiştir. Uluslararası terörizmle mücadele konusunda ABD'ye verdiği destek karşılığında ABD'nin, Rusya'nın Çeçenistan politikasına göz yummasını sağlamıştır. ABD'nin çevreleme politikasına karşılık Ukrayna, Gürcistan, Ermenistan ve Estonya'yı kontrolü altında tutabilmek için, bu ülkelere zaman zaman düşük fiyatlı doğal gaz satışına son vererek, kimi zaman da gaz arzını düşürerek veya gaz akışını keserek ya da Gürcistan örneğinde olduğu gibi güç kullanarak elinden geleni yapmaktan çekinmemiştir. Türkiye ve İran üzerinden oluşturulmak istenen alternatif boru hattı projelerinin önüne geçerek, doğalgazdaki tekel konumunu devam ettirmiştir (Yılmaz, 2008: 43). AB'nin alternatif kaynak arayışlarına rağmen, Rusya hala AB'nin en büyük doğalgaz tedarikçisi konumundadır. Rusya, uyguladığı bu politikalarla Orta Doğu ve Afrika'da hesaba katılması gereken bir devlet konumuna gelmiştir (Ulusaler, 2012: 11).

ABD'nin Polonya ve Çek Cumhuriyeti'ne füze kalkanı yerleştirmesini kendine karşı bir tehdit olarak algılayan Putin yönetimi, 1990'da imzalanan Avrupa Konvansiyonel Kuvvetler Anlaşmasından çıkma tehdidinde bulunmuştur (İyikan, 2009: 257). 2008'de Gürcistan ile yaşanan çatışma, Eski Sovyet Cumhuriyetlerine, Rusya'dan bağımsız bir politika izlememeleri konusunda bir uyarı olmuştur.

\footnotetext{
${ }^{17}$ Rusya yönetiminde söz sahibi olan Yahudi zenginler.

${ }^{18}$ World Bank (2014)'ten elde edilen veriler kullanılarak, tarafımızdan hesaplanmıştır.

19 Rusya'nın, sadece bir gücün kontrolü altındaki tek kutuplu uluslararası düzene karşı, önleyici bir rol üstlenmesi gerektiğini ifade eden görüş.
} 
Kesin zaferle sonuçlanan bu çatışma, Rusya Federasyonu'nun eski parlak günlerine geri döndüğünün bir işaret olarak görülmüştür (Erol ve Demir, 2012: 24).

\section{ENERJI POLITIKIKALARI BAĞLAMINDA RUS-AMERIKKAN MÜCADELESİ}

Soğuk savaşın sona ermesiyle birlikte ABD, Avrasya bölgesindeki hegemonyasını kurma, Rusya Federasyonu ise eski Sovyet topraklarında nüfuzunu devam ettirme çabasına girişmiştir. ABD ve Rusya Federasyonu arasındaki sorunlar, başta Hazar bölgesinden çıkarılan petrol ve doğal gazın dünya pazarına arzı olmak üzere, NATO’nun genişleme süreci ve Rusya'nın buna tepkisi ve Doğu Avrupa Füze Kalkanı Projesi gibi alanlarda devam etmiştir (Öztürk, 2009: 4).

ABD'nin enerji politikası; mümkün oldukça kendi kaynaklarının muhafaza edilmesi, ihtiyaç duyulan enerjinin farklı bölgelerden temin edilmesi ve kendine karşı bir enerji jeopolitiğini engelleme üzerine bina edilmiştir (Erol ve Demir, 2012: 22). Bu kapsamda Hazar enerji kaynaklarını elinde bulunduran SSCB, gözünü Ortadoğu petrollerine diktiğinde, ABD buna tepki göstermiştir (Nurpeiis, 2013: 524). SSCB'nin 1970'lerin sonunda Afganistan'1 işgal etmesini bu çerçevede değerlendiren dönemin Amerikan Başkanı Jimmy Carter tarihe "Carter Doktrini” olarak geçen konuşmasında, Basra Körfezi'nin kontrolünü ele geçirmeye yönelik herhangi bir girişimin, Amerikan ulusal çıkarlarına yapılmış bir saldırı olarak değerlendirileceğini ve hemen karşılık bulacağını ifade etmiştir (Polat, 2006: 67).

SSCB'nin yıkılmasıyla ABD açısından, dünyanın en zengin ikinci doğal kaynaklarının sömürülmesi için bir firsat oluşmuştur. Sınırları cetvelle çizilmiş bu ülkelerdeki halklar uzun yıllar maruz kaldıkları asimilasyon politikaları sonucunda, aniden karşılarına çıkan bağımsızlık durumuyla birlikte bir kimlik bunalımı da yaşamışlardır. Bu bunalım, özellikle Balkanlar, Kafkasya ve Orta Asya'da bir kısım iç çatışmalara yol açmıştır (Nurpeiis, 2013: 517).

1990'lardan itibaren Hazar petrolleri, ABD tarafindan yükselen petrol fiyatlarının dengelenmesinde bir önemli rol oynamıştır. Çünkü Rusya'nın OPEC benzeri ikinci bir kartel oluşturma ihtimali belirmiştir. Bu bağlamda Gürcistan, karşı cephede yer alarak kritik bir rol üstlenmiştir (Öztürk, 2009: 7). Ancak bu durum Rusya Federasyonunun tepkisini çekmiş ve 2008'de bu ülkeye karşı Güney Osetya'nın yanında silahlı çatışmaya girmesine kadar götürmüştür ${ }^{20}$. Dolayısıyla, bölge ülkeleri açısından enerji ve güvenlik iç içe geçmiş iki konudur.

ABD, Hazar ve Orta Asya bölgesindeki enerji kaynaklarının kesintisiz bir şekilde Batı'ya aktarılması için bölge ülkelerinin demokratik bir şekilde dönüşerek Batı sistemine entegre olmasını desteklemiş ve böylece bu devletleri Rus etkisinden de uzak tutmaya çalışmıştır (Öztürk, 2009: 11). Özellikle zengin doğal kaynaklara sahip olan bu stratejik ülkeleri, Batılı değerleri benimsemeleri konusunda kimi zaman desteklemiş, kimi zaman da buralarda gizli operasyonlar yürütmüştür. ABD'nin bu tavrı ülkeden ülkeye farklılık göstermiştir. Ukrayna, Gürcistan vb. gibi ülkelerde demokrasi ve insan hakları gibi değerler desteklenip renkli devrimler tasarlanırken, seçimlere hile karıştırıldığı defalarca kanıtlanmış olan Azerbaycan gibi ülkelerde, bu değerleri görmezden gelmiştir (İyikan, 2009: 264).

Orta Asya ve Kafkasya Bölgesindeki devletlerden ucuza aldığı doğalgazı, yüksek fiyatlarla Rus doğalgazına \%45 oranında bağımlı olan $\mathrm{AB}$ üyesi devletlere satan Rusya, bölgenin doğalgazını bu

\footnotetext{
${ }^{20}$ Güney Osetya; Kafkasların güneyinde yer alan, ihtilaflı bölge ve kısmen tanınmış bir devlettir. SSCB zamanında Gürcistan Cumhuriyeti bünyesinde kurulmuş Güney Osetya Otonom Oblast'1 (Rus idaresi tarafından atanmış bir valisi ve yerel olarak seçilmiş bir idare meclisi bulunan yönetim birimi), 1990 yılında Gürcistan'dan ayrılarak bağımsızlığını ilan etmiş ve Güney Osetya Cumhuriyeti adını almıştır. Buna karşılık Gürcistan, Güney Osetya'nın özerkliğini kaldırarak, bölgeyi güçle geri almaya çalışmış, bunun sonucunda 1991-1992 Güney Osetya Savaşı yaşanmış ama Gürcistan istediğini elde edememiştir. 2004 ve 2008 yıllarında iki defa daha güç kullanarak bölgeyi ele geçirmeye çalışan Gürcistan'a karşı Rusya Oset'lerin yanında yer almış ve 2008 Güney Osetya Savaşı sonunda Oset ve Rus güçleri, bölge üzerinde tam kontrolü ele geçirerek bölgenin de facto (kısmen tanınmış) bağımsızlığını sağlamışlardır. Günümüzde Rusya, Venezuela, Nikaragua, Nauru ve Tuvalu, Güney Osetya'yı bağımsız bir devlet olarak tanımıştır.
} 
devletler üzerinde bir baskı aracı olarak kullanmaktadır. Böylece Rusya doğalgaz üzerinden çok büyük kârlar elde etmektedir (Erbil, 2010: 42).

Zengin hidrokarbon (petrol, doğal gaz, vb.) kaynaklarına ev sahipliği yapan Azerbaycan, iki kutbun mücadele alanlarından birisi haline gelmiştir. Nüfusunun Şii olması yönüyle İran'ın, Rusya Federasyonu'nun etki sahasında olması yönüyle Rusya'nın, artan üretimine sağlayacağı enerji kaynağı açısından iyi bir alternatif olması yönüyle Çin'in ve sahip olduğu stratejik konum itibariyle Bölgede söz sahibi olmak isteyen ABD'nin bu ülke üzerinde derin planları bulunmakta ve bu nedenle Azerbaycan'ın önemi her geçen gün daha da artmaktadır. Azerbaycan, Rusya Federasyonundan daha bağımsız hareket edebilmek amacıyla enerji kaynaklarının dünyanın diğer bölgelerine taşınması için ABD'ye yaklaşmıştır. ABD, yakın müttefiklerini de yanına alarak, Azerbaycan'dan çıkan petrolün Bakü-Ceyhan-Tiflis Boru hattıyla dünya pazarlarına sunulmasını planlamıştır. Bu projeyle aynı zamanda diğer alternatif olan İran topraklarının kullanılması by-pass edilmiştir. Böylece zaten zengin petrol ve doğalgaz kaynaklarına sahip olan İran'ın, bir de enerji koridoru haline gelerek, konumunu daha da güçlendirmesini engellemiş ve bu bölgenin Rusya-Çin nüfuzuna geçmesinin önlenmesi konusunda önemli bir avantaj sağlamıştır. Ayrıca, Rusya'nın Avrupalı devletlere karşı enerji kartını oynamasının önüne geçebilmek amacıyla, Romanya ve Bulgaristan'a NATO üyeliği verilmesini sağlayarak, Karadeniz'e çıkış imkânını elde etmiş̧tir. (İyikan, 2009: 262).

Stratejik öneme sahip olan Hürmüz Boğazı'ndan ABD, Çin ve AB'nin akaryakıt ihtiyacının \%40'1 taşınmaktadır. Haziran 2013'te İran'da yapılan seçimleri 1lımlı ve reformist lider Hasan Ruhani'nin kazanması sonrasında, bu ülkenin Batıyla olan ilişkilerinde bir yumuşama yaşanmaya başlamıştır (Doster, 2013: 57). Böylece petrolün taşınması için daha ekonomik bir güzergâh olan İran topraklarının kullanılma ihtimali belirmiştir. Bu durum Türkiye'yi de yakından ilgilendirmektedir. Çünkü böyle bir durumda, Bakü-Ceyhan-Tiflis petrol boru hattının önemi azalacak ve 1 Mart tezkeresiyle ABD için daha az güvenilir bir ülke olarak Türkiye, Doğudan İran, güneyden ise Suriye ve Kuzey Irak Bölgesel yönetimi tarafından çevrelenmiş ve böylece bölgesel lider olma imkânları azaltılmış olacaktır (İyikan, 2009: 266).

$A B$ ve $A B D$ açısından Rusya, toparlanan askeri ve ekonomik gücü ve enerji açısından stratejik bölgelere yakınlığı dolayısıyla, dikkat edilmesi gereken bir güç olarak varlığını devam ettirmektedir. Batılı örgütler Rusya'yı uzaklaştırmaktan ziyade onu "stratejik ortak" olarak algılamak istemektedirler. NATO'nun genişleme stratejisi, AB'nin Rusya ile geliştirdiği ilişkilere zarar vermekle beraber, NATO içerisinde de Almanya ve Fransa'nın başını çektiği belli ülkelerden bu politikaya itirazlar yükselmektedir (Özer, 2008: 179).

İhtiyaç duyduğu enerjinin önemli bir bölümünü Orta Doğu ve Hazar bölgesinden sağlayan ABD, hem enerji konusunda OPEC'e olan bağımlılığını azaltmak, hem de Rusya'nın bu bölgedeki etkinliğini kırmak istemektedir. ABD için enerji ve güvenlik iç içedir ve Avrupa'nın bu konuda Rusya'ya olan bağımlılığının azaltılması gerektiğini düşünmektedir. $\mathrm{AB}$, dünyanın en fazla enerji tüketen ikinci bölgesi ve en büyük enerji ithalatçı konumundadır. AB enerji konusunda Rusya'ya olan bağımlılı̆̆ını azaltmak amacıyla ihtiyaç duyduğu enerjiyi çeşitlendirip doğal gaz ve petrolü temin ettiği kaynakları artırma yoluna gitmektedir. Bu çerçevede Bakü-Ceyhan-Tiflis gibi nispeten daha güvenli ve müttefik ülkelerden geçen hatlar inşa etmek istemektedir (Önal, 2010: 68).

$A B$, yeni üyelerinin artan üretimlerini karşılayabilmek amacıyla, istikrarlı bir Rusya'ya daha fazla ihtiyaç duymaktadır. Bu kapsamda AB ile Rusya, enerji konusunda işbirliği yapmaktadır. Söz konusu enerji diyalogu kapsamında $\mathrm{AB}$, enerji arzı güvenliğini garanti altına almak için Rusya ile işbirliğini artırmak istemektedir. Bu kapsamda Avrupalı petrol şirketleri, Rusya Federasyonu topraklarında faaliyet gösterebilmek için gerekli anlaşmaları yapmaktadırlar (Yılmaz, 2008: 47). Putin, Batılı petrol şirketleriyle işbirliğine sıcak bakmakla birlikte, bu kritik sektör üzerindeki devlet kontrolünü elinde tutmaya kararlı gözükmektedir. Rus pazarının Batılı şirketlere açılması, ancak Rus devletinin bu alandaki düzenlemeleri tamamlamasıyla mümkün gözükmektedir (Özer, 2008: 182).

ABD, enerji konusunda her zaman Rusya Federasyonuyla bir çatışma içinde değildir. İki ülke zaman zaman Kazakistan petrolünü Karadeniz'e taşıyacak boru hattının inşasında olduğu gibi işbirliği de yapabilmektedir (Erol ve Demir, 2012: 27). ABD'nin Avrasya'da artan etkinliğine karşı, Rusya bölgedeki enerji kaynaklarının kendi topraklarından geçerek Karadeniz'deki limanlarına aktarılarak 
pazarlanması stratejisini takip etmiştir. Bu amaçla Sovyet Rusya zamanından kalan boru hatlarının yanı sıra yeni hatlar inşa etme yoluna da gitmiştir. Son dönemde Rusya Federasyonu bölgede iki farklı politika takip etmiştir. Birincisi; dönemin başbakanı Viktor Chernomirdin'in uyguladığı ve bölgedeki ülkelerle ticari işbirliğini öngören yaklaşım, ikincisi de sorunlara daha sert ve tek taraflı bir yaklaşım öngören Monrovski Doktrini'dir (Öztürk, 2009: 13). Putin'in iktidara gelmesiyle Rusya Federasyonu enerji konusunda büyük atılım yapmış, Gazprom'u bir dünya şirketi haline getirmiştir (Erbil, 2010: 57). Bundan sonraki süreçte Rusya Federasyonu enerjiyi bir dış politika aracı olarak kullanmaya başlamıştır. ABD'nin insan hakları ihlalleriyle suçladığı Özbekistan'ın Rusya Federasyonu ile doğal gaz anlaşmaları imzalaması ve ülkedeki Amerikan askeri üssünü kapatması, ABD’nin Orta Asya'da inisiyatifi kaybettiği biçiminde değerlendirilebilmektedir (Nurpeiis, 2013: 531).

ABD ve AB'nin NATO aracıllğıyla Balkanlar'da etkili olmak istemesine karşılık Rusya Federasyonu, AB'yi enerji konusunda tehdit etmektedir. 2008'deki Gürcü-Rus savaşında ABD'nin etkisiz kalması sonucunda, Gürcistan toprak bütünlüğünü kaybetmiştir. Kafkaslarda ve Karadeniz çevresinde Rusya Federasyonu'nu bölgeden uzaklaştırmak isteyen ABD tarafindan 10 Ekim 1997'de kurulan GUAM (Gürcistan, Ukrayna, Azerbaycan ve Moldova) örgütü dağılmıştır (Nurpeiis, 2013: 518).

Ukrayna'da 2004'te gerçekleşen Turuncu Devrimin ardından 2006 ve 2009'da Rusya bu ülkeye ve $A B$ ülkelerine olan doğalgaz sevkiyatını kesmiş̦tir. Bunun sonucunda Ukrayna'da 2010'da yapılan seçimleri Rus yanlısı Yanukoviç kazanmıştır. Bu durum, Rusya'nın enerji kartını ne kadar iyi oynadığını göstermesi ve yakın çevresinde bulunan ülkelerin iç politikalarına yön vermesi açısından kayda değerdir (Erbil, 2010: 66).

\section{SONUÇ}

21. yüzy1lda doğal gaz ve petrol, bütün devletler için stratejik öneme sahiptir. Dünyadaki önemli hidrokarbon yatakları önemli oranda Orta Doğu ve Kafkasya gibi sorunlu bölgelerde bulunmaktadır. Bir başka deyişle bu kaynaklar, söz konusu bölgeleri sorunlu hale getirmektedir. Yani enerji kaynakları üzerinde hâkimiyet kurmak isteyen küresel ve bölgesel güçler, aralarında çatışarak buralarda sorun yaşanmasını sürekli hale getirmektedirler. Bu durum, gelişmiş ve gelişmekte olan ve enerjide dışa bağımlı olan ülkeler için enerji arz güvenliği konusunu da gündeme getirmektedir. Azalan kaynaklarla birlikte enerjinin güvenli bir şekilde hedef ülkelere ulaştırılamaması, enerji fiyatlarının artmasına ve küresel ekonominin türbülansa girmesine neden olmaktadır.

Soğuk Savaş'ın sona ermesi başta Doğu Avrupa, Orta Asya ve Kafkaslar olmak üzere bütün dünyada dengeleri değiştirmiştir. Liberal dünya zaferini ilan etmiş ve ABD dünyada rakipsiz kalmıştır. 1990'lı yıllarda SSCB'nin boşalttı̆̆ 1 alanlarda milliyetçilik merkezli iç çatışmalar çıkmıştır. ABD buralarda hâkimiyet kurmak isterken, SSCB'nin devamı niteliğindeki Rusya Federasyonu buralardaki nüfuzunu korumak istemiştir. SSCB'nin yıkılmasından hemen sonra, bu ülkede Batı yanlısı bir dış politika izlenmiş, ancak sonraki dönemde yerini Avrasyacı yaklaşımlara bırakmıştır. Putin'in iktidara gelmesiyle Rusya Federasyonu, ülke içinde istikrarı yakalayarak, dış politikada strateji değişikliğine gitmiştir. Bu döneme kadar uygulanan askeri stratejilerin yerini, enerjinin ön planda olduğu ekonomik çıkarlar almıştır. Özellikle Orta Asya ve Kafkaslarda günümüze kadar yaşanan krizlerin arkasında, bu bölgede yer alan enerji kaynaklarına ve bu kaynakları nakledecek petrol boru hattı güzergâhlarına hâkim olma mücadelesi yatmaktadır. Son yıllarda Rusya Federasyonu enerji kartını, eski Doğu Bloğu ve $A B$ ülkelerine karşı etkili bir biçimde kullanmıştır. Bu bağlamda Rusya Federasyonu, Batı ile bazen çatışan bazen de işbirliğine dayalı bir politika izlediği görüntüsü vermektedir. 


\section{KAYNAKÇA}

AKA, A. (2009), Antonio Gramsci ve Hegemonik Okul, Balıkesir Üniversitesi Sosyal Bilimler Enstitüsü Dergisi, Cilt 12, Say1 21, ss.329-338.

ARMAOĞLU, F. (1983), 20. Yüzyıl Siyasi Tarihi (1914-1980), Türkiye İş Bankası Yayınları, No: 909.82, Ankara.

AYKAÇ, M., Parlak, Z. ve Özdemir, S. (2009), Küreselleşme Sürecinde Rekabet Gücünün Arttırlması ve Türkiye'de KOBİ'ler, İstanbul Ticaret Odası Yayınları, No: 2009-24.

BLANK, S. (2007), U.S. Interests in Central Asia and the Challenges to Them, Carlisle, PA: Strategic Studies Institute, U.S. Army War College.

CANKARA, P. ve CANKARA, Y. (2007), Vladimir Putin Döneminde Rus Dış Politikasında Yapılan Değişiklikler, Süleyman Demirel Üniversitesi, Sosyal Bilimler Dergisi, Sayı: 15, ss. 193-212.

ÇífTÇİ, K. (2009), Soğuk Savaş Sonrasında ABD: Rızaya Dayalı Hegemonyadan Imparatorluk Düzenine, ZKÜ Sosyal Bilimler Dergisi, Cilt 5, Sayı 10, 2009, ss. 203-219.

ÇOĞAL, N. (2014), Çok Kutuplu Dünya Projesi: Şangay İşbirliği Örgütü, http://www.nejatcogal.com/index.php?option=com_content\&task=view\&id=49\&Itemid=25, [15.02.2014].

DOĞAN, N. (2012), Uluslararası İlişkiler ve Rasyonellik: Bürokratik Politikanın Alana Katklsı ve Geleceğin Öngörülmesinde Rasyonellik Varsayımının Önemi, Dokuz Eylül Üniversitesi Sosyal Bilimler Enstitüsü Dergisi, Cilt: 14, Sayı: 3, ss. 85-103.

DOSTER, B. (2013), Ortadoğu Analiz, Cilt:5, Say1: 54, ss. 54-61.

ERBİL, Y. (2010), Rusya-Ukrayna Doğalgaz Krizi ve Enerji Güvenliği, Yayınlanmamış Yüksek Lisans Tezi, Kadir Has Üniversitesi Sosyal Bilimler Enstitüsü, Kayseri.

EROL, M.S. ve DEMIR, S. (2012), Amerika'nın Karadeniz Politikasını Yeniden Değerlendirmek, Akademik Bakış, Cilt: 6, Sayı: 11, ss. 17-33.

GÖKTEN, K. (2011), Çin'in Barış̧̧ll Yükselişine Muhafazakâr-Realist “Çözümler”, Akdeniz İ.İ.B.F. Dergisi, Sayı: 21, ss.110-129. 
GÜRKAN, C. ve KARAHANOĞULLARI, Y. (2013), Vergi Devletine Kuramsal Yaklaşımlar, Maliye Dergisi, Say1: 165, ss. 1-26.

İYİKAN, N. (2009), ABD’nin Azerbaycan İlişkilerine Etki Eden Parametreler, Selçuk Üniversitesi Sosyal Bilimler Enstitüsü Dergisi, Sayı: 21, ss. 255-267.

KATZMAN, K. (2005), Iraq: U.S. Regime Change Efforts and Post-Saddam Governance, CRS Report for Congress, January 28, http://www.law.umaryland.edu/marshall/crsreports/ crsdocuments/RL3133901282005.pdf, [14.02.2014].

KİBAROĞLU, M. (2002), 11 Eylül Ardından Strateji, Tehdit ve Caydırıcılık, Foreign Policy, Ocak, http://www.mustafakibaroglu.com/sitebuildercontent/sitebuilderfiles/Kibaroglu-11

EylulArdndanStratejiTehditCaydiricilik-22dec01.pdf, [14.02.2014].

MİKAİL, E. H. (2007), Rus Dış Politikası ve Yeni Çar Putin, Kilim Matbaası, Konya.

NOGAIEVA, A. (2010), ABD'nin Orta Asya'daki Demokratikleştirme Politikaları: Araçlar, Devrim Denemeleri ve Sonuçlar, Uluslararası Stratejik Araştırmalar Kurulu, Cilt: 5, Sayı: 10, ss. 59-91.

NURPEIIS, L. (2013), 20'inci Yüzyıldan 21'inci Yüzyıla Geçişte Jeopolitik Kırılmalar ve Yeni Dengelerin Oluşumu, Turkish Studies-International Periodical For The Languages, Literature and History of Turkish or Turkic, Cilt: 8, Say1: 5, ss. 515-529.

ÖNAL, H. (2010), ABD’nin Afganistan Politikasının Açmazları: Bölgesel Bir Analiz, Uluslararası Hukuk ve Politika, Cilt: 6, Sayı: 23 ss.43-71.

ÖZER, S. (2008), Avrupa Birliği Rusya ve ABD’nin Avrupa Güvenliğine Farklı Yaklaşımlarının Transatlantik İttifakına Etkileri, Akdeniz İ.İ.B.F. Dergisi, Sayı: 15, ss.170-195.

ÖZKAN, B. (2011), Soğuk Savaş Sonrası Amerikan Dış Politikası, Stratejik Araştırmalar ve Etüt Merkezi, Cilt: 9, Say1:16, ss. 51-91.

ÖZTÜRK, A. (2009), Rusya-Gürcistan Krizi: Yerel Bir Çatışma, Küresel Yansımalar, Uluslararas1 Stratejik Araştırmalar Kurulu, Cilt: 4, Sayı: 7, ss.1-27.

POLAT, İ. (2006), 11 Eylül Terör Saldırlları ve Amerika Birleşik Devletlerinin Afganistan Müdahalesi, Süleyman Demirel Üniversitesi, Sosyal Bilimler Enstitüsü, Yayımlanmamış Yüksek Lisans Tezi.

SCHOUTEN, P. (2009), Theory Talks: Robert Cox on World Orders, Historical Change, and the Purpose of Theory in International Relations, Theory Talks, http://www.theorytalks. org/2010/03/theory-talk-37.html [14.02.2014]. 
SMITH, A. (1776), Ulusların Zenginliği, Çevirenler: Ayşe Yunus ve Mehmet Bakırcı, Yayın Y11: 1997, Alan Yayınc1lık, Bursa.

SÖNMEZ, S. (2010a), Moskova'nın Kutuplaşma Çabaları: Putin Dönemi Rus Dış Politikası, Avrasya Etütleri, Sayı: 37, ss.37-76.

SÖNMEZ, S. (2010b), Yeni Batıcılık ve Yeni Avrasyacılık Akımları Bağlamında Yeltsin Yönetimi’nin Doğu Batı Politikalarının Analiz, Akademik Bakış, Cilt: 3, Sayı: 6, ss.73-97.

SÜMER, G. (2008), Amerikan Dış Politikasının Kökenleri ve Amerikan Dış Politik Kültürü, Uluslararası İliş̧kiler, Cilt: 5, Sayı: 19, ss. 119-144.

TUNÇ, H. (2009), Preemption in the Bush Doctrine: A Reappraisal, Foreign Policy Analysis, Vol: 5, Issue: 1, pp. 4-5.

TÜRKMEN, İ. (2002), Önleyici Müdahale, http://hurarsiv.hurriyet.com.tr/goster/haber. aspx?id=101711, [15.02.2014].

ULUSALER, K. (2012), Yeni Putin Dönemi'nin Enerji Sektörüne Etkileri, Cumhuriyet Enerji, Say1: 28, ss.11-12.

WORLD BANK (2014), Statistics, http://data.worldbank.org/indicator/NY.GDP.MKTP.CD, [15.02.2014].

YALÇINER, S. (2007), Putin Dönemi Rusya Federasyonu-NATO İlişkileri, Süleyman Demirel Üniversitesi İktisadi İdari Bilimler Fakültesi, Cilt:12, Sayı:2, ss.339-358.

YILDIRIM, E., LOPCU, K., ÇAKMAKLI, S. ve ÖZKAN, Ö. (2010), Yeni Keynesyen Makro Ekonomik Bir Model: Türkiye Uygulaması, Ege Akademik Bakış, Cilt: 10, Sayı: 4 , ss. 1269-1277.

YILMAZ, S. (2008), Uluslararası İlişkilerde Güç ve Güç Dengesinin Evrimi, Stratejik Araştırmalar Dergisi, Cilt:1, Say1: 1,ss. 27-65. 